Jurnal Maksipreneur, Vol.V, No. 1, Desember 2015 Hal. 134 - 159

\title{
EVALUASI KINERJA PENGELOLAAN OBYEK WISATA PANTAI DI DIY
}

Teguh Budi Prasetya, M Si (teguhbudiprasetya@gmail.com)

Fakultas Isipol Universitas Proklamasi 45 Yogyakarta

Dra. Endang Susilowati, SU (susilowati1945@yahoo.co.id)

Fakultas Isipol Universitas Proklamasi 45 Yogyakarta

Drs. Bambang Sugeng D, MM (bsugengd@yahoo.co.id)

Fakultas Isipol Universitas Proklamasi 45 Yogyakarta

\begin{abstract}
With the potential is so great, Beach-Tourism can be regarded as a new future for the industrial tourism in DIY. Character exotic beaches and not much exploited accompanied the opening of the South Cross Road Line (JJLS:Jalur Jalan Lintas Selatan) resulted Beach Tourism in this province has a very bright future. Development of beach tourism, especially in the karst area of Gunung Kidul will be a key growth area in the region's economy. The problem is, the management of existing beach-tourism destination is still so bad. Shore excursions still tend to be chaotic, expensive, dirty and aggravated expansion "asong-traders" to coastal areas that tend to interfere with the comfort of tourists .. Finally the beach resort far from friendly for tourists. This condition is believed, not to be separated from the failure of the management model in controlling the perpetrators of beach - tourism. This research generally want to formulate a model of partisipative management of beach-tourism on DIY and able to put into a beachtourist travel featured DIY sector. In the first year (part I), research will evaluating against existing beach-tourist management model with the aim of getting information: Existing forms of institutional model and regulatory management of DIY beach tourism, strengths, weaknesses, opportunities and challenges faced, strategic issues of institutional development model of DIY beach tourism, At this stage of the research will be conducted evaluative and utilizing SWOT analysis to formulate a raw material for the development of the model.
\end{abstract}

Key words: management model, participatory, beach tourism, 


\section{PENDAHULUAN}

Ada tiga kata kunci penting yang tidak bisa dipisahkan dari proses pembangunan di DIY; kata itu adalah pariwisata, kebudayaan dan pendidikan. Begitu pentingnya ketiga kata kunci itu, sehingga kemudian dirumuskan sebagai "tiga pilar utama pembangunan" Daerah Istimewa Yogyakarta. Pemilihan tiga pilar itu bukannya tanpa sebab, selain Yogyakarta selama ini memiliki posisi yang amat kuat di sektor pendidikan dan kebudayaan, pada kenyataannya kedua pilar tadi juga
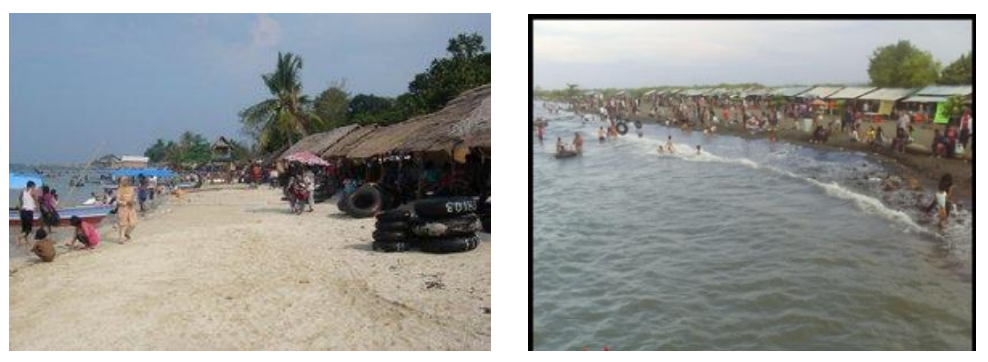

Gambar

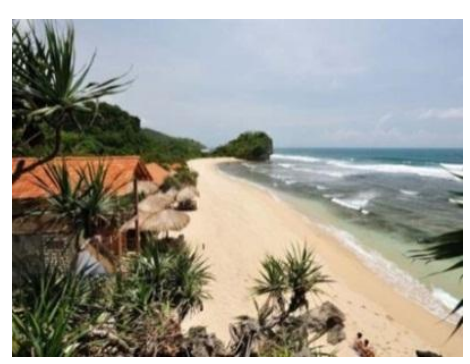

KONDISI AKTUAL OBWIS PANTAI DI DIY

memperkokoh pilar kepariwisataan, dan menambah berkah perekonomian DIY. Tak dapat dipungkiri, ketiga pilar utama itu membawa dampak tidak saja dampak sosial, namun juga kebudayaan dan ekonomi DIY.

Diantara berbagai kawasan dan sektor pembangunan, "kawasan pantai selatan" DIY termasuk salah satu primadona pembangunan ekonomi-pariwisata. Potensi pantai karst nan eksotik di Gunungkidul, Pembukaan Jalur Lingkar Selatan (JJLS), serta rencana pembangunan bandara baru di Kulonprogo tentu akan membuka konektivitas transportasi dan ekonomi yang lebih cepat. Hal ini juga diungkapkan Kepala Dinas Pariwisata DIY Tazbir Abdulah. (http:// www. visitingjogja.comindex. php? mod=detail_berita\&id=1484\#tengah $h$ :).

Namun demikian, faktanya sektor wisata pantai di DIY sat ini masih menghadapi banyak tantangan tantangan yang tidak mudah untuk diatasi. Berbagai keluhan yang banyak dilontarkan pengunjung adalah persoalan layanan yang mahal, kumuh, tidak tertib, semrawut, pungutan ganda, penyerobotan pantai oleh berbagai aktivitas bisnis menjadikan wisata pantai di DIY kurang menarik minat. 
Hal inilah yang menjadi alasan wisman hengkang dari Parangtritis dan wisata pantai DIY lain selama ini.

Namun diluar fakta buram di atas, ada obwis pantai (Indrayanti/Pulang Syawal) yang terlihat memiliki model pengelolaan dan kinerja pengelolaan yang sedikit berbeda degan obwis pantai lainnya

Fakta yang dikemukakan di atas diduga kuat karena adanya kelemahan "pengelolaan" wisata pantai. Kelembagaan yang masih bersifat sektoral dengan ujung tombak Dinas Pariwisata nampak tidak mampu membendung ekspansi kepentingan ekonomi yang masuk. Akibatnya pengelolaan wisata pantai menjadi terasa kedodoran, karena tidak mampu mengatur berbagai kepentingan yang masuk di sektor ini.

Pertanyaan-besarnya adalah, "adakah yang salah dengan model pengelolaan eksisting ?". Penelitian Tahap I ini bertujuan mengevaluasi model pengelolaan eksisting obwis pantai di DIY. Pada saatnya dalam penelitian Tahap II, akan dicoba dirumuskan model pengelolaan yang melibatkan semua stakeholder, menerapkan konsep goodgovernance dan efektif.

\section{TINJAUAN PUSTAKA}

Model pengelolaan obwis (obyek wisata) pantai di DIY barangkali sudah memiliki sejarah setua obyek wisata pantai itu sendiri. Berkembang dalam bentuk kelembagaan yang amat sederhana, hingga berkembang menjadi model kelembagaan yang semakin kompleks, sejalan dengan semakin kompleksnya berbagai kepentingan yang masuk dalam industri wisata pantai ini. Regulator (pemerintah), pengelola lokal, kelompok parkir, pedagang besar-kecil, hotel, restoran, wisatawan macanegara dan wisatawan dalam negeri berebut kawasan obwis yang luasnya terbatas. Relasi antar stakeholder dalam menyelenggarakan layanan publik ini dikelnal dengan "kelembagaan" obwis pantai.

Konsep kelembagaan menurut Esman dan Blaise dalam Potter dalam Thomas dkk (1972), merupakan suatu proses sehingga kebiasaan-kebiasaan dalam bertindak serta nilai-nilai antar hubungan dapat mapan. Sedangkan Parsons (1966), 
mempergunakan terminologi institutionalization sebagai suatu integrasi menurut pengalaman para aktor dalam suatu sistem dan peran yang relevan.

Menurut definisinya, beberapa pengertian kelembagaan dapat disajikan sebagai berikut:

a. .....aturan di dalam suatu kelompok masyarakat atau organisasi yang menfasilitasi koordinasi antar anggotanya untuk membantu mereka dengan harapan di mana setiap orang dapat bekerjasama atau berhubungan satu dengan yang lain untuk mencapai tujuan bersama yang diinginkan (Ruttan dan Hayami, 1984).

b. ....aturan dan rambu-rambu sebagai panduan yang dipakai oleh para anggota suatu organisasi (Ostrom, 1985; 1986).

c. .... suatu himpunan atau tatanan norma-norma dan tingkah laku yang bisa berlaku dalam suatu periode tertentu untuk melayani tujuan kolektif yang akan menjadi nilai bersama. Institusi ditekankan pada norma-norma perilaku, nilai budaya dan adat istiadat (Uphoff, 1986).

d. .....sekumpulan batasan atau faktor pengendali yang mengatur hubungan perilaku antar anggota atau antar kelompok. Dengan definisi ini kebanyakan organisasi umumnya adalah institusi karena organisasi umumnya mempunyai aturan yang mengatur hubungan antar anggota maupun dengan orang lain di luar organisasi itu (Nabli dan Nugent, 1989).

e. .....aturan main di dalam suatu kelompok sosial dan sangat dipengaruhi oleh faktor-faktor ekonomi, sosial dan politik. Institusi dapat berupa aturan formal atau dalam bentuk kode etik informal yang disepakati bersama. North membedakan antara institusi dari organisasi dan mengatakan bahwa institusi adalah aturan main sedangkan organisasi adalah pemainnya (North, 1990).

f. .....mencakup penataan institusi (institutional arrangement) untuk memadukan organisasi dan institusi. Penataan institusi adalah suatu penataan hubungan antara unit-unit ekonomi yang mengatur cara unit-unit ini apakah dapat bekerjasama dan atau berkompetisi. Dalam pendekatan ini organisasi adalah suatu pertanyaan mengenai aktor atau pelaku ekonomi di mana ada kontrak atau 
transaksi yang dilakukan dan tujuan utama kontrak adalah mengurangi biaya transaksi (Williamson, 1985).

Berdasar beberapa definisi tentang kelembagaan tersebut di atas, maka dapat dipahami bahwa kelembagaan adalah suatu tatanan dan pola hubungan antara anggota masyarakat atau organisasi yang saling mengikat yang dapat menentukan bentuk hubungan antar manusia atau antara organisasi yang diwadahi dalam suatu organisasi atau jaringan dan ditentukan oleh faktor-faktor pembatas dan pengikat berupa norma, kode etik, aturan formal maupun informal untuk pengendalian prilaku sosial serta insentif untuk bekerjasama dan mencapai tujuan bersama.

Terkait dengan pengelolaan Obyek wisata pantai, maka kelembagaan yang dimaksud kelembagaan obyek wisata pantai dalam penelitian adalah suatu tatanan dan pola hubungan antar pihak (stakeholder) dalam penglolaan obyek wisata pantai. Ia meliputi pihak-pihak yang menjalankan fungsi regulasi, fungsi operasi, dan fungsi kontrol.

Berbicara tentang kelembagaan pengelolaan obyek wisata pantai, akan terkait dengan peran empat stakeholder utama, yaitu Pemerintah Daerah, masyarakat sekitar obwis, dunia usaha dan pengguna layanan. Pemerintah Kabupaten dalam pengelolaan wisata pantai menduduki posisi yang cukup sentral. Dinas Pariwisata misalnya berperan merumuskan arah kebijakan pengembangan, mengatur dan menyediakan infrastruktur obyek wisata; Dinas Dinas Perijinan berperan mengeluarkan ijin usaha, jasa wisata, Bappeda menetapkan RTRW (rencana tata ruang wilayah), Dinas Pendapatan Daerah memungut retribusi daerah ( Perda Kab. Bantul No 5/2003, Perda Kab. Bantul No 3/ Th 2003, RIPDA Pariwisata DIY ). Tidak kalah penting adalah Pemerintah Desa yang banyak mnangani kelompok lokal pengelola obwis.

Stakeholder lain adalah dunia usaha (bisnis), atau dalam Perda disebut usaha jasa pariwisata. Adalah setiap usaha yang bergerak di bidang pelayanan jasa pariwisata yang meliputi jasa biro perjalanan wisata, jasa agen perjalanan wisata, jasa pramuwisata, jasa informasi pariwisata, jasa konsultan pariwisata, dan jasa konvensi, perjalanan insentif serta pameran; (Pasal 1 ayat 7: Perda Kab Bantul No 
3/2005 tentang Perijinan Usaha Jasa Pariwisata di Kab. Bantul). Para pengusaha inilah yang sesungguhnya menghubungkan wisatawan dengan obyek wisata. mereka juga memberi layanan langsung kepada wisatawan di obyek wisata.

Stakeholder yang lain adalah masyarakat sekitar obwis. Masyarakat disini adalah mereka yang tinggal disekitar obyek wisata dan mendapat penghidupan dari kegiatan pariwisata. Mereka biasa menyediakan jasa parkir, kamarmandi, warung, restoran dan pedagang asong.

Stakeholder ke empat adalah Wisatawan baik wisman maupun wisdom. Mereka adalah para pengunjung obyek wisata yang ingin mendapatkan jasa layanan wisata. Wisatawan yang datang dikenakan retribusi obyek wisata, namun juga menuntut layanan wisata yang layak sesuai ekspektasi mereka.

Jika dipetakan maka konfigurasi kelembagaan Eksisting adalah sebagai berikut:

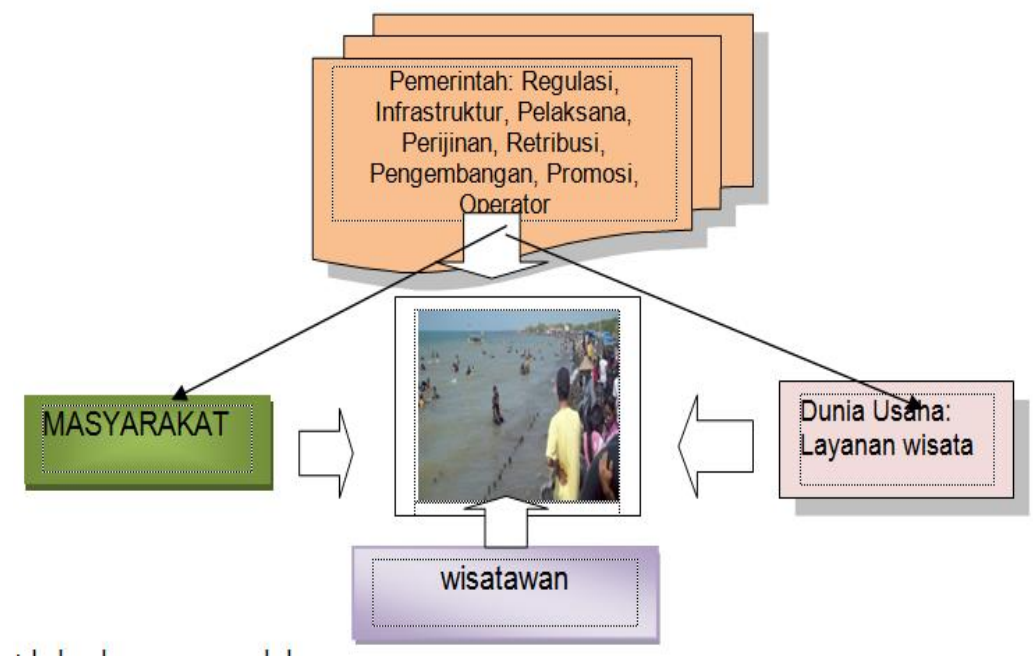

Terlihat kelembagaan pengelolaan pariwisata pantai di DIY masih bersifat parsial, dimana fungsi-fungsi regulasi, operasi, kontrol masih tersebar ke dalam berbagai kelembagaan. Pemerintah Daerah masih mengemban peranan sentral, tidak saja regulasi, tapi juga investasi, perijinan, dan peran-peran lain. Sementra Dunia Usaha dan masyarakat sekedar mengisi peran-peran lain yang tidak dilakukan oleh Pemerintah Kabupaten.

Kelemahan model kelembagaan ini adalah lemahnya kordinasi dan rendahnya komitmen elemen-elemen non regulatif (dunia usaha dan masyarakat) untuk 
mentaati regulasi yang ditetapkan pemerintah. Mereka tidak merasa memiliki, membuat dan merumuskan regulasi, sehingga sering tidak bertanggungjawab untuk mentaatinya. Peran berlebihan pemerintah juga mengindikasikan belum berjalannya prinsip good goveernance yang mengutamakan parisipasi publik.

Sinyalemen ini tidak jauh berbeda dengan hasil penelitian Joanna Adamowicz 2010, yang dimuat dalam European Countryside MENDELU, dikatakan bahwa "The biggest impediments are: inconsistent legal framework, incompatible infrastructure for increased number of tourists where there are no long-term strategies for development because of the instability of local authorities which hampers the co-operation of tourism management, nature conservation and municipalities as the responsibilities are not clearly agreed. Yet, local initiatives have found innovative ways to combine tourism, nature conservation and generate income. (Europ. Countrys. 3· 2010 • p. 118-131 DOI: 10.2478/v10091-010-00091)

\section{a. Reformasi Model Pengelolaan Kelembagaan Menuju Praktek Good Governance}

Sebagai sebuah gagasan, good governance kadangkala masih jauh dari realitas dan memerlukan perjuangan panjang untuk mewujudkannya. Bahkan pertanyaan kritis diajukan oleh Agus Dwiyanto ( 2006;17 ) yakni apakah good governace bukan hanya mitos? Jawaban menjadi tidak mudah karena konsep good governance tersebut memiliki arti luas dan seringkali berbedabeda. Agar tidak menjadi sekedar mitos, Agus Dwiyanto menyarankan beberapa karakteristik dan nilai yang harus diusahakan ada pada praktek good governance antara lain : Pertama, Praktek good governance harus memberi ruang kepada aktor lembaga non pemerintah untuk berperan serta secara optimal dalam kegiatan pemerintahan sehinga memungkinkan adanya sinergi diantara aktor dan lembaga pemerintah dan non pemerintah seperti masyarakat sipil dan mekanisme pasar. Kedua, praktek good governance terkandung nilai-nilai (efisiensi, keadilan dan daya tanggap ) yang membuat pemerintah dapat lebih efektif bekerja untuk mewujudkan kesejahteraan 
bersama. Ketiga, praktek good governance adalah praktek pemerintahan yang bersih dari KKN serta berorientasi pada kepentingan publik. Oleh karena praktek pemerintahan dinilai baik bila mampu mewujudkan transparansi, penegakan hukum dan akuntabilitas publik.

Ketiga prinsip tersebut yang menjadi pilar utama yang membedakan tata kelola yang menjalankan gagasan good governance dengan tata kelola pemerintahan yang lain. Partisipasi, efisiensi, efektifitas, daya tanggap, akuntabilitas, transparansi, bersih dan berorientasi kepada kepentingan publik menjadi ciri praktik good governance.

Dalam perspektif ini kelembagaan layanan publik seperti pengelolaan obyek wisata pantai idealnya disusun dengan berdasarkan prinsip-prinsip good governance itu. Karena dengan demikian praktek layanan publik akan lebih transparan, partisipatif, bersih dan profesional. Secara konseptional, hingga saai ini model layanan publik sendiri sudah mengalami banyak pergeseran paradigma dan nilai-nilai ( Warsono, 2007 ) sebagai berikut:

a. Perubahan dari orientasi sistem pemerintahan yang sarwa negara ke orientasi sistem pasar ( market).

b. Perubahan dari orientasi lembaga pemerintahan yang kuat, besar dan otoritarian menjadi berorientasi pada small dan less government, egalitarian dan demokratis.

c. Perubahan dari sentralistis kekuasaan menjadi desentralisasi kewenangan.

d. Perubahan menajemen pemerintahan yang menekankan batas-batas dan aturan yang berlaku hanya untuk satu negara saja, ke arah boundaryless organization, akibat globalisasi

e. Perubahan dari tatanan birokrasi Weberian menjadi tatanan birokrasi yang post bureucratic government ( Rouke, 1992 ), dan post bureucartic organization (Heckscher dan Donnellon, 1994), atau perubahan dari manajemen pemerintahan yang mengikuti stuktur fisik ( physical structure ) ke tatanan manajemen pemerintahan yang berdasarkan logical stucture ( Henry Lucas, 1996 ) 
f.Perubahan dari a low trust society ke arah a high trust society ( Fukuyama, 1995).

\section{METODE PENELITIAN}

Penelitian akan dilaksanakan dalam 2 tahap (dua tahun anggaran). Secara sederhana penelitian akan berjalan dalam 2 (dua) tahap penelitian. Masing masing tahap penelitian akan memiliki tujuan khusus.

\section{Proses Penelitian Tahun I}

Penelitian Tahun pertama lebih bersifat evaluatif terhadap Model Pengelolaan eksisting, melakukan review regulasi dan kajian teoritik terhadap model pengelolaan obyek wisata pantai. Kajian evaluasi kelembagaan dilakukan untuk mendapatkan gambaran model pengelolaan terkini, sedangkan kajian regulasi dan teoritik untuk memperoleh gambaran model pengelolaan idealregulatif.

Secara sederhana alur penelitian tahun pertama tergambar dalam bagan berikut:

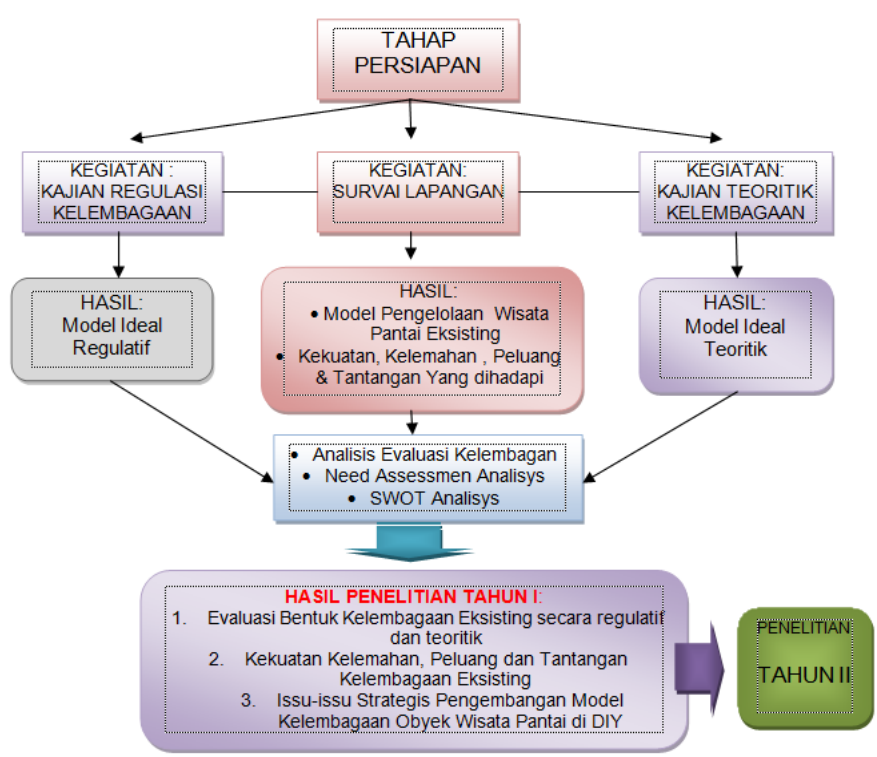


2. Lokasi Penelitian:

Penelitian Tahun pertama mengambil lokasi di tiga Kabupaten yang memiliki kawasan obwis pantai, yakni Kabupaten Gunungkidul, Bantul dan Kulonprogo. Sasaran pengumpulan data adalah:

1. Regulator : Dinas Pariwisata, Pemerintah Desa di Kab Gunungkidul dan Kulon Progo

2. Obyek Wisata Pantai 10 buah

3. Pengunjung Obyek WISATA

4. Pelaku usaha

Data yang akan dikumpulkan berupa data primer (digali dengan survai baik dengan wawancara dan observasi), data sekunder (laporan, dokumen regulasi dan data internet)

\section{ANALISIS DATA}

Analisis penelitian ini mengikuti alur penelitian evaluasi, meskipun dengan model paling sederhana; secara sederhana analisis akan dilakukan dengan cara :

a. Mengidentifikasi Kondisi Ideal Model Penglelolaan Obyek Wisata Pantai dengan melihat Tugas Pokok dan Fungsi Institusi Pengelola Obyek Wisata Pantai dan Peran Ideal Sistem Pengelola Obyek Wisata Pantai

b. Mendata kondisi Model Pengelola Obyek Wisata Pantai eksisting, di ke 10 obyek wisata, dan mengkodifikasikan menjadi data yang terstruktur, sehingga memudahkan proses evaluasi.

c. Mengevaluasi kinerja Lembaga Pengelola Obyek Wisata Pantai, dengan cara membandingkan kondisi ideal dan kondisi eksisting; untuk kemudian dapat dilakukan evaluasi.

d. Mengidentifikasi Kekuatan, Kelemahan, Tantangan dan peluang yang dimiliki oleh Institusi Pengelola Obyek Wisata Pantai, serta ekspektasi masyarakat akan sistem transportasi yang diinginkan, melalui analisis SWOT 


\section{KINERJA PENGELOLAAN WISATA PANTAI GUNUNGKIDUL DAN KULONPROGO}

a. Kebijakan Pengelolaan Obwis Pantai di DIY

Gunungkidul termasuk kabupaten yang menyadari betul bahwa salah satu jalan keluar terbaik untuk mengatasi keterbatasan sumberdaya alam dan kemiskinan adalah pariwisata. Pariwisata alam adalah sektor yang amat potensial di Gunungkidul, karena kabupaten ini memiliki puluhan titik destinasi wisata pantai baik yang sudah eksis maupun yang potensial dikembangkan, ratusan goa dan kawasan karst yang kaya akan potensi wisata. Untuk itu, kabupaten ini merasa perlu membuat payung hukum yang kuat yang dapat menjadi acuan pengembangan industri pariwisata. Beberapa produk hukum daerah yang sudah diterbitkan diantaranya adalah:

1) Peraturan Daerah Gunungkidul Nomor 2 Tahun 2010 tentang Rencana Pembangunan Jangka Panjang Daerah Kabupaten Gunungkidul Tahun 20052025

2) Peraturan Daerah Kabupaten Gunungkidul Nomor 6 Tahun 2011 tentang

Rencana Tata Ruang Wilayah Kabupaten Gunungkidul Tahun 2010-2030 (Lembaran Daerah Kabupaten Gunungkidul Tahun 2011 .

3) Perda Kabupaten Gunungkidul no 5 tahun 2013 tentang Penyelenggaraan Kepariwisataan

4) Serta RIPARDA (Rencana Induk Pembangunan Kepariwisataan Daerah) Gunungkidul 2014-2025.

Riparda 2014-2025 ini misalnya menetapkan pembangunan pariwisata dalam beberapa zona Kawasan Strategis Pariwisata (KSP). Beberapa Obyek Wisata Pantai masuk dalam KSP 1-3

Kulonprogo adalah salah satu Kabupaten di Provinsi Yogyakarta. Meski kabupaten ini dikatakan sebagai kabupaten terbelakang di Yogyakarta, namun dalam hal pariwisata cukup potensial sekali, begitu banyak obyek wisata khususnya wisata alam yang dapat kita kunjungi di tempat ini. Beberapa produk hukum daerah yang sudah diterbitkan diantaranya adalah: 
1) Perda No. 1 tahun 2010 yang telah direvisi dengan Perda No. 08 Tahun 2013, tentang Retribusi Tempat Rekreasi dan Olahraga.

2) Dalam rangka penggalian PAD dari wisata saat ini juga sudah disiapkan perda pengganti tinggal tunggu penomoran, dengan perda yang baru diharapkan dapat menjadi daya tarik pengunjung wisata karena ke depan pungutan retribusi kendaraan wisata akan dihilangkan.

3) Serta RIPARDA (Rencana Induk Pembangunan Kepariwisataan Daerah) Kulonprogo 2014-2025.

Riparda 2014-2025 ini menetapkan pembangunan pariwisata dalam beberapa zona Kawasan Strategis Pariwisata (KSP). Kawasan pariwisata Kulonprogo terbagi menjadi: Wilayah Utara atau Bukit Menoreh Wilayah selatan (Kawasan Pantai Glagah, Congot dan Trisik). Pada Wilayah Selatan ini Kulon Progo memiliki beberapa obyek wisata pantai.

b. Problem dan Tantangan Kelembagaan Obwis Pantai

Menjalankan fungsi di atas Dinas Kebudayaan dan Kepariwisataan Kabupaten Gunungkidul mengkordinir camat dan kepala desa untuk membentuk, mengawasi dan mengendalikan pengelolaan obyek wisata, sebab Dinas tidak mungkin sendirian mengawasi dan mengendalikan pengelolaan obyek wisata.

Kepala Desa misalnya diberikan kewenangan untuk menyetujui kepengurusan dan pendirian Kelompok Sadar Wisata (Pokdarwis) di tiap tiap obyek wisata. Pemkab misalnya menetapkan bahwa di tiap obyek wisata dikelola oleh sebuah Pokdarwis. Hanya Pokdarwis yang memenuhi syarat-syarat tertentu yang akan dikukuhkan oleh Pemkab sebagai pengelola obyek wisata.

Mengingat besarnya animo masyarakat untuk terlibat dalam kegiatan pariwisata, serta untuk menghindari terjadinya konflik antar kelompok maka Pemkab menetapkan kebijakan 1 (satu) Pokdarwis untuk satu obyek wisata. Seleksi dilakukan dengan menetapkan syarat-yarat pendirian Pokdarwis, diantaranya memiliki AD-ART, memiliki kepengurusan yang disyahkan oleh Pemerintah Desa (Pemdes) dan memiliki anggota sekurang-kurangnya 25 orang yang terdiri dari 
pemangku kepentingan di tiap obyek wisata seperti pedagang, tukang parkir, nelayan.

Peneliti juga menilai belum berhasilnya Pemkab membentuk Pokdarwis yang sehat diantaranya dikarenakan masih belum jelasnya apa peran pokdarwis dalam skema pengembangan obyek wisata setempat. Sebagian masyarakat menilai pembentukan pokdarwis sebagai sesuatu yang kurang penting. Hasilnya, dari ratusan obyek wisata yang potensial dikembangkan di Gunungkidul baru ada sekitar sembilan Pokdarwis yang telah dikukuhkan oleh Pemkab Gunungkidul.

Jika dievaluasi berdasarkan teori kelembagaan, dimana kelembagaan layanan publik mestinya dipisahkan ke dalam tiga fungi utama yaitu regulasi atau pengaturan, operasi atau pelaksanaan layanan wisata dan kelembagaan yang menjalankan fungsi kontrol terlihat beberapa fenomena sebagai berikut:

\begin{tabular}{|c|c|c|c|}
\hline Aspek & GUNUNG KIDUL & BANTUL & KULON PROGO \\
\hline Potensi Wisata Pantai & $\begin{array}{l}\text { Cukup besar, belum } \\
\text { berkembang }\end{array}$ & $\begin{array}{l}\text { Cukup besar, } \\
\text { Sudah Stagnan }\end{array}$ & $\begin{array}{l}\text { Besar, obyek baru } \\
\text { sedang dikembangkan }\end{array}$ \\
\hline $\begin{array}{l}\text { Ketersediaan Payung } \\
\text { Hukum /RIPARDA }\end{array}$ & $\begin{array}{l}\text { - Baru saja diundangkan, } \\
\text { mulai dijadikan acuan. } \\
\text { - Zona Pengembangan } \\
\text { Wisata sudah dimiliki }\end{array}$ & $\begin{array}{l}\text { Riparda Lama out- } \\
\text { ofdate, Riparda Baru } \\
\text { belum ditetapkan }\end{array}$ & $\begin{array}{l}\text { Riparda dalam proses } \\
\text { penetapan, }\end{array}$ \\
\hline $\begin{array}{l}\text { Harapan Pemda terhadap } \\
\text { Pengembangan Obwis } \\
\text { Pantai }\end{array}$ & $\begin{array}{l}\text { Obwis Pantai dianggap } \\
\text { Peluang besar untuk } \\
\text { perekonomian GK, wil. } \\
\text { Selatan. }\end{array}$ & $\begin{array}{l}\text { Ob-Wis Pantai menjadi } \\
\text { obyek yang harus } \\
\text { dipertahankan } \\
\text { keberlangsungannya }\end{array}$ & $\begin{array}{l}\text { Obwis Pantai kurang } \\
\text { menjadi prioritas } \\
\text { pengembangan } \\
\text { ekonomi }\end{array}$ \\
\hline $\begin{array}{l}\text { Peran Pemda Dalam } \\
\text { Pengelola an Obwis Pantai }\end{array}$ & $\begin{array}{l}\text { - Menyediakan } \\
\text { infrastruktur } \\
\text { - Mengatur Pokdarwis } \\
\text { (pengelola Lokal), } \\
\text { - Pemungutan Retribusi } \\
\text { - Membina dan memberi } \\
\text { Bantuan Pokdarwis }\end{array}$ & $\begin{array}{l}\text { - Menyediakan } \\
\text { Infrastruktur, } \\
\text { - Pemungutan retribusi } \\
\text { - Memediasi konflik } \\
\text { antar kelompok } \\
\text { - Kebersihan Obwis }\end{array}$ & $\begin{array}{l}\text { - Penyediaan } \\
\text { Infrastruktur } \\
\text { - Pemungutan } \\
\text { Retribusi }\end{array}$ \\
\hline $\begin{array}{l}\text { Bentuk Kelembagaan } \\
\text { Pengelo la Lokal }\end{array}$ & $\begin{array}{l}\text { Pokdarwis, Pem Desa } \\
\text { Investor }\end{array}$ & $\begin{array}{l}\text { Pok. Masyarakat } \\
\text { Setempat }\end{array}$ & $\begin{array}{l}\text { Pok Pemuda, dengan } \\
\text { berbagai kondisi }\end{array}$ \\
\hline
\end{tabular}

\section{1) Fungsi Pengaturan/regulasi}

Fungsi ini sebagian besar dijalankan oleh Pemkab melalui Dinas Pariwisata dan Kebudayaan, telah berhasil membuat regulasi besar dan berjangka panjang. Berbagai Perda dan Riparda telah berhasil disusun. Namun beberapa regulasi teknis belum terumuskan dalam bentuk regulasi, yang mampu menjadi acuan penyelenggaraan layanan wisata pantai. Pemkab/Dinas Pariwisata dan 
Kebudayaan masih menggunakan "nilai" untuk memberi arah layanan obyek wisata. Nilai tersebut misalnya Sadar Wisata, Sapta Pesona dan Penetapan Zona khusus pada obyek wisata.

Pokdarwis yang mestinya menjalankan pengaturan lokal, seperti penerapan zona layanan wisata (parkir, dagang, istirahat, MCK dll) belum mampu merumuskannya ke dalam sebuah Keputusan Pokdarwis yang akomodatif terhadap semua kepentingan stakeholder.

Kondisi ini banyak terkait dari belum berkembangnya pokdarwis sebagai kelembagaan pengelola lokal obwis pantai.

2) Fungsi Pelaksanaan / Operasi

Kabupaten gunungkidul penyediaan sarana prasarana makro dijalankan oleh Pemkab. Dalam penyediaan sarana dan prasarana obyek wisata, Pemerintah Kab. Gunungkidul sudah memiliki tekad kuat untuk mengembangkan standard layanan obwis yang tinggi, sesuai dengan prinsip Sapta Pesona Pariwisata. Namun dalam pelaksanaannya sejumlah kendala masih menghadang proses penyediaan sarana dan prasarana pariwisata.

Pertama, Pemkab tidak selalu memiliki tanah/lahan yang cukup untuk memenuhi kebutuhan pembangunan sarana dan prasarana. Beberapa sarana membutuhkan lahan yang luas, seperti akses jalan, zona parkir, pedestrian dan zona pedagang dan pendukung (MCK). Sebagian besar tanah berstatus Hak Milik perorangan dan Sultan Ground (SG) dan Paku Alam Ground (PAG). Akibatnya penyediaan sapras menjadi tidak mudah dan membutuhkan beaya yang besar. Kedua, potensi obyek wisata dalam bentang alam yang amat luas (sepanjang pantai Gunungkidul), mengakibatkan alokasi pendanaan dan penganggaran yang tidak mudah. Prioritas obwis harus dilakukan dengan hati hati dan tajam. Ketiga, pengurusan ijin penggunaan lahan SG dan PAG sekarang ini bukan perkara mudah. Keempat, animo masyarakat yang amat besar, melebihi kemampuan Pemkab untuk menyediakan akses dan Sapras di semua obyek wisata. Sekarang ini hampir di setiap akses masuk ke pantai dikembangkan obwis pantai dengan inisiatif masyarakat sendiri. Yang paling 
penting dalam pengelolaan layanan wisata (operasi) adalah fungsi yang dilaksanakan oleh kelembagaan Lokal yang di Gunungkidul dijalankan oleh Pokdarwis. Pokdarwislah yang diharapkan dapat menyelenggarakan sistem keamanan dan ketertiban, kenyamanan dan kebersihan obyek wisata serta menjalankan kegiatan pendukung pariwisata seperti parkir dan layanan MCK serta perdagangan (kuliner dan cendera mata). Kenyataannya, fungsi yang sudah dijalankan baru sekedar penataan parkir, pengaturan pedagang, yang inipun tidak mudah dilakukan. (analisis detail tentang kinerja Pokdarwis disajikan dalam bab lain dari laporan ini).Perhatian pokdarwis masih berkutat pada persoalan "perdagangan" dan kegiatan ekonomi pariwisata lain, dan belum banyak menjangkau persoalan "hospitality" obyek wisata.

3) Fungsi Monitoring dan Pengendalian

Fungsi ini penting untuk memastikan bahwa layanan wisata pantai sesuai dengan garis kebijakan kepariwisataan daerah yang mampu mendorong aktivitas ekonomi masyarakat, dan ramah terhadap kelestarian lingkungan dan pendidikan; serta taat terhadap semua peraturan yang berlaku. Namun nampaknya fungsi ini belum digarap secara serius, terlihat dari belum jelasnya unit kelembagaan yang menghadle kegiatan ini. monitoring juga tidak mudah dilaksanakan, karena berbagai standard layanan obyek wisata belum dirumuskan secara tertulis oleh Pemerintah Kabupaten dan oleh Pokdarwis (untuk aturan internal). Selama ini monitoring lebih dibebankan pada Pemerintah Desa, tanpa pelimpahan kewenangan dan mekanisme monitoring yang baik. Pemerintah biasanya baru membuat laporan ketika sebuah insiden di obyek wisata terjadi.

\section{c. Hasil Pengelolaan Obyek Wisata}

Untuk melihat sejauh mana kinerja yang telah dihasilkan oleh kelembagaan pengelolaan Obwis DIY, pertama tama dapat dipahami dari gambaran umum yang dirangkum dalam tabel berikut ini:

1) Gunung Kidul merupakan kabupaten di DIY yang memiliki potensi wisata pantai yang paling besar. Hampir sepanjang garis pantai Gunung Kidul 
berpotensi menjadi obyek pariwisata yang bisa dikembangkan. Ini tidak lepas dari karakter pantai gunungkidul yang bertemu dengan tegakan bukit karst, melahirkan pantai berpasir putih, dan eksotik. Sementara itu Potensi obwis pantai di Bantul sudah lama di garap. Hampir semua potensi wisata pantai sudah digarap. Nama besar Parangtritis, Parangkusumo, Depok dan Samas sudah lama di kenal. Kegiatan wisata pantai sudah berkembang menjadi industri wisata yang menghidupi banyak pihak. Kulonprogo, terrmasuk kabuaten yang tidak terlalu memiliki potensi wisata pantai yang tinggi. Beberapa Obwis yang lama sudah digarap, seperti Congot dan Glagah tidak menunjukkan perkembangan yang berarti. Obyek lain memiliki tantangan besar untuk pengembangannya, karena obak yang besar, abrasi pantai yang tinggi dan kurang tersedia akses jalan yang memadai untuk dikembangkan.

2) Dari fakta di atas, maka terlihat komitmen Pemkab untuk mengembangkan obyek wisata (khususnya pantai) tidak sama satu dengan yang lain. Kulonprogo nampak amat berharap agar industri wisata ini menjadi masa depan pengembangan perekonomian masyarakat. Sadar akan hal itu, maka Kab. Gunungkidul melengkapi pengembangn obwis dengan payung hukum yang cukup kuat, yakni RIPARDA (Rencana Indik Pengembangan Pariwisata Daerah) dalam bentuk Perda. Sementara itu Bantul dan Kulonprogo belum kunjung menyelesaikan draft RIPARDA, untuk menggantikan RIPARDA yang telah lama habis masa berlaku.

3) Harapan Pemkab terhadap Obwis juga ada perbedaan yang cukup menyolok. Hal ini terlihat dari hasil wawancara peneliti dengan Dinas Pariwisata setempat. Pemda Gunungkidul (yang karena keterbatasan potensi daerahnya), meihat Pariwisata Pantai sebagai masa depan pengembangan ekonomi masyarakat kawasan selatan Gunungkidul. Kab. Bantul terlihat sekedar melihat Obwis Pantai sebagai aset yang perlu dipelihara keberlangsungannya; dan Kulonprogo terlihat tidak menempatkan pariwisata pantai sebagai prioritas pembangunan pariwisata daerah. 
4) Akhirnya ketiga hal di atas juga mempengaruhi peran yang diambil Pemkab, melalui Dinas Pariwisata dan Dinas terkait lainnya terhadap Obwis Pantai. Pemkab Gunungkidul setidaknya menempatkan dirinya menjadi penyedia infrastruktur obwis, meregulasi pokdarwis (menyeleksi dan mengatur), memungut retribusi daerah dan membina dan memberi bantuan Pokdarwis. Pokdarwis adalah Kelompok Sadar Wisata, sebuah kelompok lokal yang mewadahi berbagai kepentingan yang ada, dan menjadi pengelola obwis di tingkat lokal. Peran Pemkab Bantul sedikit berbeda, mereka mengaku berperan untuk menyediakan infrastruktur dan akses obwis pantai, memungut retribusi memediasi konflik antar kelompok yang terjadi dan mengelola kebersihan obwis. Sementara itu di Pemkab Kulonprogo lebih berperan sebagai penyedia infrastruktur dan memungut retribusi wisata.

5) Bentuk Kelembagaan Pengelola Lokal di ketiga kabupaten juga berbeda; Di Gunungkidul setiap obyek dikelola oleh sebuah Pokdarwis yang di daftarkan ke Pemkab, diatur dan dibina oleh Pemkab. Pokdarwis di Gunungkidul beberapa sudah mampu menyepakati aturan main yang mengikat pihak-pihak pelaku wisata. Di Bantul, dalam sebuah obwis sering dikelola oleh beberapa kelompok masyarakat yang masing-masing kelompok mengelola sebuah urusan atau kawasan wisata tertentu. Standard pelayanan di obwis Bantul menjadi beraneka ragam . tidak jarang konflik antar kelompok tidak terelakkan. Dalam keadaan demikian peran Pemkab menjadi dubutuhkan. Di Kulonprogo, setiap obwis dikelola oleh kelompok masyarakat (pemuda/karangtaruna). karena obwis relatif sepi, tidak banyak terjadi konflik antar kelompok. Namun kelompok ini cenderung berkembang secara alamiah dan jauh dari standard pelayanan obwis modern. Indikator lain yang dapat dipahami untuk kinerja kelembagaan yang kedua adalah dengan melihat bentuk kelembagaan di masing masing wilayah obwis pantai. Gambaran tersebut nampak dalam tabel berikut : 


\begin{tabular}{|c|c|c|c|}
\hline Aspek & GUNUNGKIDUL & BANTUL & KULON PROGO \\
\hline $\begin{array}{l}\text { Stakeholder yg } \\
\text { terlibat }\end{array}$ & $\begin{array}{l}\text { Pemdes, Masyarakat } \\
\text { Setempat, Investor, } \\
\text { Pedagang }\end{array}$ & $\begin{array}{l}\text { Pemdes, Masyarakat } \\
\text { Setempat, Investor, } \\
\text { Pedagang }\end{array}$ & $\begin{array}{l}\text { Pemdes, Masyarakat } \\
\text { Setempat, Investor, } \\
\text { Pedagang }\end{array}$ \\
\hline $\begin{array}{l}\text { Bentuk Pengelola } \\
\text { Lokal }\end{array}$ & $\begin{array}{l}\text { Pok-Darwis (representasi } \\
\text { stakeholder) } \\
1 \text { pokdarwis/lokasi, } \\
\text { Ada seleksi pokdarwis }\end{array}$ & $\begin{array}{l}\text { Kelompok kelompok } \\
\text { kepentingan, cenderung } \\
\text { berjalan sendiri-sendiri }\end{array}$ & $\begin{array}{l}\text { Kelompok-kelompok } \\
\text { Masyarakat,/Pemuda }\end{array}$ \\
\hline $\begin{array}{l}\text { Fungsi Pengelola } \\
\text { Lokal }\end{array}$ & $\begin{array}{l}\text { - Pengaturan internal } \\
\text { obwis } \\
\text { - Pelayanan wisata } \\
\text { - Meredam konflik antar } \\
\text { kelompok } \\
\text { - Mengatur zonasi obwis } \\
\text { - Implementasi aturan } \\
\text { - Kebersihan obyek }\end{array}$ & $\begin{array}{l}\text { - Menjadi kelompok- } \\
\text { kelompok } \\
\text { kepentingan } \\
\text { - Mengelola zona zona } \\
\text { internal } \\
\text { - Berhubungan dan } \\
\text { berkompromi dg } \\
\text { kelompok lain } \\
\text { - Mengelola parkir }\end{array}$ & $\begin{array}{l}\text { - Melakukan pelayanan } \\
\text { - Menjlik } \\
\text { kepentingan } \\
\text { kelompok } \\
\text { - Tiap obwis punya } \\
\text { beberapa kelompok } \\
\text { kepentingan }\end{array}$ \\
\hline $\begin{array}{l}\text { Kinerja Pengelola } \\
\text { Lokal }\end{array}$ & $\begin{array}{l}\text { Untuk Pokdarwis yg sudah } \\
\text { maju: } \\
\text { - Mampu mengorganisir } \\
\text { - } \text { stakeholder pariwisata } \\
\text { - Mampu mengendalikan } \\
\text { - Merredam konflik } \\
\text { - Mampu mengelola } \\
\text { - } \text { standard layanan wisata } \\
\text { baik } \\
\text { - Kebersihan cukup baik } \\
\text { - Cenderung mudah } \\
\text { diregulasi }\end{array}$ & $\begin{array}{l}\text { Obwis Lama: } \\
\text { - Terlalu banyak } \\
\text { kelompok } \\
\text { kepentingan } \\
\text { - Susah mencapai } \\
\text { kesepakatan } \\
\text { - Tiap kelompok } \\
\text { terkesan jalan sendiri } \\
\text { - Ketegangan antar } \\
\text { kelompok tinggi } \\
\text { - Layanan wisata } \\
\text { cenderung rendah } \\
\text { - Kebersihan tangg- } \\
\text { jawab pemda } \\
\text { - Agak susah diregulasi } \\
\text { Obwis Baru: } \\
\text { - Cenderung lebih } \\
\text { teratur. Depok } \\
\text { cenderung punya } \\
\text { kinerja bagus }\end{array}$ & $\begin{array}{l}\text { - Kurang bisa mencapai } \\
\text { - Ponsensus } \\
\text { Pelayanan berjalan } \\
\text { alamiah, cenderung } \\
\text { seadanya } \\
\text { - Kebersihan kurang } \\
\text { bagus } \\
\text { - Kinerja cenderung } \\
\text { seadanya }\end{array}$ \\
\hline
\end{tabular}

\section{Keterangan :}

1. Stakeholder yang bermain di Obwis Pantai

Hampir sama di ketiga kabupaten, setiap obwis memiliki banyak kelompok kepentingan yang ikut menentukan kualitas layanan wisata pantai di DIY. Kelompok-kelompok kepentingan yang dapat diidentifikasi adalah Pemerintah Desa, Kelompok Masyarakat Setempat, Investor dan pedagang. Semakin ramai sebuah obyek wisata, maka jumlah kelompok kepentingan yang bermain semakin banyak. Kelompok-kelompok tadi terpecah menjadi kelompok kepentingan baru sesuai kepentingan yang mereka usung. Sehingga muncul kelompok parkir, kelompok pedagang asong, kelompok pedagang payung, kelompok restoran dll. Obwis lama dengan skala wisaata yang tinggi memiliki sejumlah kelompok kepentingan yang lebih kompleks. Parangritis adalah gambaran obwis semacam itu. Dalam keadaanyya seperti sekarang Parang tritis 
menjadi obwis yang paling susah mencapai kesepakatan dan pengaturannya. Bentuk Kelompok Lokal :di Gunungkidul adalah Kelompok Sadar Wisata (1 kelompok/obwis), Bantul: Kelompok Kelompok Pengelola Obwis (sesuai dengan spesialisasi urusannya), dan di Kulonprogo adalah Kelompok Masyarakat / Pemuda.

2. Fungsi Kelompok Pengelola Lokal

Di GK, Pokdarwis menyandang fungsi mengatur layanan obwis, pengaturan internal, peredam dan intermediasi konflik antar pemangku kepentingan, mengatur zonasi obwis, menegakkan aturan internal serta mengelola kebersihan obwis. Di Bantul kelompok-kelompok pengelola berfungsi menjadi kelompokkelompok aspirasi kepentingan, mengelola zona-zona yang menjadi zona kekuasannya, berhubungan dan berkompromi dengan kelompok lain, dan mengelola parkir . Agak sulit mendorong kelompok-kelompok ini membangun kesepakatan internal untuk menentukan standardisasi layanan wisata. Di Kulonprogo, kelompok masyarakat berfungsi menjalankan layanan wisata (terbatas), menjadi mediator konflik antar kelompok, mengelola parkir.

3. Kinerja Kelompok Lokal dalam Pelayanan Wisata

- Di Gunungkidul:

Untuk Pokdarwis yang sudah di akui oleh Pemkab, biasanya sudah mampu mengorganisir stakeholder yang ada, mampu mengatasi konflik internal emlalui kesepakatan-kesepakatan internal, mulai mampu menerapkan standard layanan wisata yang baik, menjaga ketertiban obwis, kebersihan dan cenderung mudah diregulasi oleh pemerintah.Namun untuk Pokdarwis yang belum diregistrasi, kondisinya belum sebaik Pokdarwis maju. Namun biasanya ini ada pada obwis yang belum berkembang maju.

- Di Bantul :

Pada Obyek Wisata lama, kelompok kelompok pengelola cenderung susah mencapai kesepakatan, sehingga di Bantul setiap obwis bisa dikelola oleh beberapa kelompok, dan tidak jarang pengunjung terkena aturan yang berganda, dengan stndard layanan yang berbeda-beda. Antar kelompok ini 
cenderung susah mencapai kesepakatan, sehingga standard layanan juga tak kunjung dapat didefinisikan. Tiap kelompok berjalan dengan aturannya sendiri, konflik dan persaingan antar keompok cenderung tinggi sehingga standard layanan eksisting cenderung berjalan seadanya. Kelompok pengelola semacam ini cenderung susah diregulasi oleh Pemkab. Pada Obyek Wisata Baru, seperti Depok, cenderung lebih terrtib karena belum banyak stakeholder yang masuk. Kinerja kelompok masih amat ditentukan oleh tokoh setempat yang karismatik. Depok termasuk obwis baru yang memiliki tokoh lokal yang memiliki komitmen wisata yang tinggi.

- Kulonprogo:

Kemompok yang masih berkembang secara alamiah cenderung melaksanakan pengelolaan wisata secara apa adanya, kinerjanya kurang bagus dan cenderung tiak memiliki standard layanan yang disepakati.

d. Kekuatan, Kelemahan, Peluang dan Tantangan Pengelolaan Obwis Pantai

\begin{tabular}{|c|c|c|c|c|}
\hline & STRENGTH & WEAKNESESS & OPPORTUNITIES & TIGHT \\
\hline $\begin{array}{l}\text { GUNUNG } \\
\text { KIDUL }\end{array}$ & 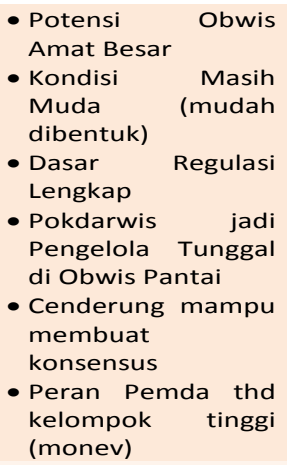 & $\begin{array}{l}\text { - Ekosistem wisata } \\
\text { belum terbentuk, } \\
\text { kondisi } \\
\text { kelembagaan } \\
\text { masih sederhana } \\
\text { - Visi pengelola } \\
\text { masih terbatas } \\
\text { - Tergantung Tokoh } \\
\text { setempat }\end{array}$ & $\begin{array}{l}\text { - Pembukaan JJLS } \\
\text { (jalur Jalan Lintas } \\
\text { Selatan } \\
\text { - Dukungan Pemda } \\
\text { thd Pokdarwis tinggi } \\
\text { - Bantuan Pemda thd } \\
\text { Pokdarwis "diakui" } \\
\text { banyak. }\end{array}$ & $\begin{array}{l}\text { - Persaingan antar } \\
\text { Obwis tinggi } \\
\text { - Tuntutan pengguna } \\
\text { layanan tinggi } \\
\text { - Masuknya kekuatan } \\
\text { Ekonomi/investor }\end{array}$ \\
\hline BANTUL & $\begin{array}{l}\text { - Kelompok sudah } \\
\text { Lama Eksis } \\
\text { - Pengelola Lokal } \\
\text { sudah memahami } \\
\text { persoalan } \\
\text { - Memiliki tokoh } \\
\text { lokal yang } \\
\text { karismatik }\end{array}$ & $\begin{array}{l}\text { - Obwis tua, susah } \\
\text { diregulasi } \\
\text { - Ketegangan antar } \\
\text { kelompok tinggi } \\
\text { - Stakeholder } \\
\text { cenderung banyak } \\
\text { - Cenderung susah } \\
\text { membuat } \\
\text { konsensus } \\
\text { - Peran Pemda } \\
\text { terbatas } \\
\text { - Standar layanan } \\
\text { tak jelas }\end{array}$ & $\begin{array}{l}\text { - SDM banyak } \\
\text { - Fasilitas wisata } \\
\text { komlet } \\
\text { - Obwis } \\
\text { terkenal sudah } \\
\text { - Dukungan Pemda } \\
\text { lumayan tinggi }\end{array}$ & $\begin{array}{l}\text { - Persaingan antar } \\
\text { Obwis tinggi } \\
\text { - Tuntutan pengguna } \\
\text { layanan tinggi } \\
\text { Masuknya kekuatan } \\
\text { Ekonomi/investor }\end{array}$ \\
\hline KL PROGO & $\begin{array}{l}\text { - Persoalan yang } \\
\text { dihadapi masih } \\
\text { sederhana } \\
\text { - Dukungan Pemda } \\
\text { Cukup Baik dan } \\
\text { menjadi prioritas } \\
\text { pengembangan } \\
\text { - Persaingan antar } \\
\text { kelompok rendah } \\
\text { - Didominasi angkat } \\
\text { muda (pemuda) }\end{array}$ & $\begin{array}{l}\text { - } \text { Komitemen Pemda } \\
\text { agak rendah } \\
\text { - Obyek kurang } \\
\text { menarik } \\
\text { - Belum ada } \\
\text { kelompok } \\
\text { pengelola yang } \\
\text { Bagus } \\
\text { - Visi pelaku wisata } \\
\text { buruk } \\
\text { - SDM terbatas }\end{array}$ & $\begin{array}{l}\text { - SDM banyak } \\
\text { - Pesaing sedikit } \\
\text { - Obwis belum } \\
\text { berkembang } \\
\text { - Dukungan Penda } \\
\text { cukup baik } \\
\text { - Pengembangan } \\
\text { Bandara, membuka } \\
\text { akses wisata yang } \\
\text { besar }\end{array}$ & $\begin{array}{l}\text { - masuknya investor } \\
\text { di saat } \\
\text { kelembagaan belum } \\
\text { solid } \\
\text { - pesaing obwis lain } \\
\text { diluar KP } \\
\text { - tuntutan pengguna } \\
\text { layanan tinggi }\end{array}$ \\
\hline
\end{tabular}


e. Kekuatan, Kelemahan, Peluang dan Tantangan Pengelolaan Obwis Pantai Dengan memperhatikan kondisi kelembagaan pengelola obyek wisata pantai di ke tiga kabupaten di DIY di dapat beberapa kesimpuan penting :

1) Kekuatan / srengths

Pengelola Gunungkidul:

- Potensi Obwis di Gunungkidul untuk dikembangkan amatlah besar. Gunungkidul memiliki garis pantai yang sebagian besar belum dikembangkan menjadi obyek wisata; dengan terbukannya akses jalur jalan Lintas Selatan gunungkidul, maka pantai-pantai itu punya potensi untuk dikebangakan amatlah besar.

- Pengelola yang telah ada dapat dikatakan dalam kondisi "Masih Muda" dalam arti baru terbentuk, masih memiliki struktur sederhana, belum muncul potensi konflik, sehingga secaara kelembagaan kondisinya masih mudah dibentuk atau diregulasi.

- Dasar Regulasi Lengkap, dalam arti Gunungkidul telah memiliki perangkat payung hukum yang kuat untuk mengatur kelembagaan pengelola obwis pantai. RIPARDA dan berbagai aturan turunannya cukup memadai sebagai pijakan melakukan penguatan kelembagaan pengelola lokal (Pokdarwis)

- Pokdarwis jadi Pengelola Tunggal di Obwis Pantai; beda dangan kondisi di Bantul, tiap obyek wisata di Gunungkidul hanya dikelola oleh satu kelompok sadarwisata (pokdarwis) yang keanggotaannya terdiri dari berbagai unsur kepentingan; Pemda punya hak untuk menentukan kelompok mana yang syah mengelola obwis (dengan persyaratan yang regulatif), dengan tujuan memudahkan pembinaan/penguatan kelompok itu. Termasuk untuk menyalurkan berbagai program pariwisata.

- Cenderung mampu membuat konsensus. Karena hanya ada kelompok tunggal dalam setiap obwi pantai, maka konsensus menjadi lebih mudah dicapai. Pokdarwis kemudian mampu membuat kesepakatan internal untuk untuk menjaga kualitas layanan pariwisata. 
- Peran Pemda thd kelompok tinggi (monev). Pemda melalui Disparda \& Kebudayaan berhak mengakui (meregistrasi), dan membina pokdarwis pengelola obwis pantai. Disparda \& Keb. Juga melakukan pembinaan melalui Pemerintah Desa.

Pengelola Obwis Pantai Bantul:

- Kelompok Pengelola sudah Lama eksis, sehingga mereka sudah memiliki kepengurusan, aturan main dan pola kerja yang melembaga. Beberapa pengurus sudah belasan tahun berkecimpung sebagai pelaku wisata, sehinngga organisasinya sudah berjalan dengan baik.

- Pengelola Lokal sudah memahami persoalan. Karena usianya, kelompok kelompok pengelola ini sudah memmahami dengan baik persoalan-persoalan yang dihadapi. Mereka juga terlihat cukup mmampu berfungsi sebagai kelompok kepentingan, ketika harus berhadapan dengan kelompok lain

- Memiliki tokoh lokal yang karismatik. Beberapa kelompok biasanya direkatkan oleh kharisme pemimpin lokal yang mampu mengikat konsensus diantara para anggotanya. Mereka inilah yang dalam realitasnya banyak mewarnai perjalanan organisasi/kelompok itu.

Kelompok Pengelola Kab Kuloprogo.

- Persoalan yang dihadapi masih sederhana. Kelompok pengelola obwis pantai di Kulonprogo masih sederhana, sesederhana persoalan yang dihadapi. Dimana obwis pantai di Kulonprogo memang belum semaju kabupaten GK dan Bantul. Kelompok cukup memilikin legitimasi dari Pemda KP

- Dukungan Pemda Cukup Baik dan menjadi prioritas pengembangan

- Persaingan antar kelompok rendah. Karena tidak banyak kue yang diperebutkan, maka tingkat konflik di antar kelompok pengelola pantai tidak lah terlalu menonjol.

- Dikelola anak-anak muda, yang masih potensial untuk dikembangkan.

2) Kelemahan (Weaknesses)

Pengelola Obwis Pantai Gunung Kidul: 
- Ekosistem wisata belum terbentuk, kondisi kelembagaan masih sederhana. Sebagai kawasan obwis pantai, Gunungkidul tergolong kawasan muda yang belum terbentuk ekosistem pariwisatanya. Pengunjung belum banyak, penyedia layanan masih minim, sarana prasarana masih terbatas dan pengelolaan juga masih sederhana. Faktor-faktor itu saling mempengaruhi satu dengan yang lain.

- Visi pengelola masih terbatas. Pokdarwis yang baru terbentuk, rata-rata beranggotakan masyarakat setempat yang sebelumnya tidak memiliki latar belakang pengalaman wisata. Akibatnya visi dan pelayanan wisata masih terkesan seadanya.

- Tergantung Tokoh setempat. Sesuai karakter yang masih muda, pokdarwis Gunungkidul perkembangannya amat diwarnai oleh tokoh tokoh setempat, seperti kepala desa maupun ketua karang taruna.

Pengelola Obwis Pantai Bantul:

- Pengelola Obwis Tua; tterdiri dari beberapa kelompok yang terbentuk untuk melindungi kepentingan kelompoknya. Kelompok-kelompok pengelelola yang sudah mengkristal ini cenderung sulit untuk diwadahi dalam satu kelembagaan terpadu. Koordinasi dan konsensus antar kelompok sulit dilakukan. Dari pengalaman yang didapat regulator (Dinas Pariwisata), kelompok dengan pola begini tergolong sulit untuk diajak berembug, dan dikontrol oleh regulator.

- Ketegangan antar kelompok dalam sebuah obwis cenderung latent dan susah dimediasi

- Pada obyek wisata yang telah tua (Parangtritis, Samas, dll), cenderung memiliki stakeholder yang beraneka ragam dengan jalinan kerja yang cenderung rumit.

- Akhirnya peranan Pemda (dinas pariwisata) agak minimalis, karena fungsi regulasi dan pengenalian cenderung kurang berjalan.

- Kelompok-kelompok pengelola yang berjalan sendiri-sendiri mengakibatkan standard layanannya berbeda-beda dan susah didorong mencapai standard layanan yang lebih tinggi.

Pengelola Obwis Kulonprogo:

- Pengelola Obwis di Kulonrogo ini tergolong sudah tua, setua onwis yang sudah lama berkembang di Kulonprogo. Sayang obwis di sana memang tidak berkembang sesemarak Bantul dan Gunungkidul. Sehingga pengelolaannya juga cenderung stagnan 
- Komitmen Pemerintah daerah untuk mengembangkan obwis Pantai nampaknya juga kurang kuat. RIPARDA (rencana induk pengembangan pariwisata daerah) belum juga tersusun, setelah RIPARDA yang lama habis masa berlakunya.

- Visi pengeloala tentang pengembangan layanan wisata juga terkesan rendah, mereka hanya melakukan kegiatan-kegiatan yang selama ini sudah dilakukan tanpa evaluasi dan pengembangan yang memadai.

- Kelembagaan kelompok pengelola juga terkesan seadanya. Obwis hanya dikelola oleh kelompok pemuda yang lebih mengelola parkir, keamanan dan ketertiban. Belum ada mekanisme pengambilan keputusan yang demokratis, dan mekanisme organisasi yang baik.

- SDM yang begabung dalam kelompok pengelola cenderung rendah. Kelompok hanya mewadahi para pemuda/karangtaruna yang masih menganggur.

3) Peluang/ Opportunities

Beberapa situasi diluar barangkal menjadi peluang untuk mengembangkan kelompok pengelola lokal obwis pantai di DIY. Beberapa peluang tersebut adalah:

- Pengelola Obwis Gunung Kidul:

- Pembukaan Jalur jalan Lintas Selatan, bisa memjadi faktor yang membuat arus wisatawan ke obwis pantai selatan GK akan deras mengalir. Ini bisa menjadi peluang untuk pengembangan kelompok pengelola (Pokdarwis)

- Dukungan Pemerintah Daerah GK terhadap Pokdarwis dan Obwis Pantai juga amat besar; dimulai dari penerbitan RIPARDA, aturan-aturan pelaksanaannya, pembanngunann akses masuk, fasilitas wisata digelontorkan oleh Pemda. Dinas terkait juga serius menggarap ini, termasuk pembinaan Pokdarwis yang dilakukan oleh Dispar\&Kebudayaan GK.

- Pengelola Obwis Bantul:

- SDM Bantul termasuk melimpah jumlahnya, sehingga Pengelola Obwis tidak akan kekurangan SDM yang dibutuhkan

- Fasilitas Wisata juga sudah tersedia secara memadai, dari akses jalan, tempat parkir, dan berbagai kebijakan pemerintah daerah dalam penataan obwis pantai.

- Obwis Pantai di Bantul juga sudah dikenal luas dalam peta pariwisata Yogyakarta; sehingga tanpa publikasi besar-besaran pun, Wisatawan (Domestik) amat banyak datang berkunjung. 
- Dukungan Pemda terhadap pengelola juga relatif cukup baik. Sudah berbagai program di inisiasi untuk membantu pengelola memperbaiki standard layanan (termasuk proyek penataan Parangtritis), meskipun hasilnya masih belum menggembirakan.

4) Tantangan / Threats

Terdapat beberapa ancaman yang berasal dari luar yang perlu diantisipasi dalam kerangka pengembangan kelembagaan kelompok pengelola lokal obwis pantai di DIY, beberapa ancaman itu adalah:

- Pengelola Obwis Gunung Kidul - Bantul - Kulon Progo:

- Persaingan antar obyek wisata pantai amat tinggi, sehingga jika kelompok tidak cepat dibenahi menjadi kelompok pengelola yang sehat, obyek wisata akan kehilangan momentum pertumbuhan.

- Tuntutan Pengguna Layanan meningkat tinggi; obwis yng dikelola asal-asalan akan ditinggalkan pengunjung dan mendapatkan "stigma" obyek yang tak layak kunjung.

- Masuknya kekuatan pasar/investor ke sejumlah obyek wisata baru, menuntut Pokdarwis mempu menggembangkan mekanisme untuk mengakomodasi kehadiran pasar di obyek wisata mereka.

\section{DAFTAR PUSTAKA}

Adiyanti; Mira Rachmi., 2005 Arahan Bentuk, Kegiatan dan Kelembagaan Kerjasama pada Pengelolaan Sarana dan Prasarana Pantai Parangtritis, (Thesis)., Jurusan Perencanaan Wilayah dan Kota, Fak. Teknik Universita Diponegoro, Semarang 2005

Carisson; Lars., 1995 Policy Making, Collective Action, and The Governability of Society.; Paper dipresentasikan dalam The Mini Conference on Political Order and Development

European Countryside MENDELU Journal "TOWARDS SYNERGY BETWEEN TOURISM AND NATURE CONSERVATION. THE CHALLENGE FOR THE RURAL REGIONS: THE CASE OF DRAWSKIE LAKE DISTRICT, POLAND” (Europ. Countrys. · 3 $2010 \cdot$ p. 118-131 DOI: 10.2478/v10091-010-0009-1)

Gautama, IGA Gede Oka Gautama,Nyoman Sunarta;2012., Evaluasi Perkembangan Wisata Bahari, Studi kasus Pantai Sanur; Jurnal Ilmiah Pariwisata; Vol 2 no 1, hal 109-122 september 2012 
Henry, N. 1995. Public Administration and Public Affairs. Sixth Edition. Englewood Cliffs, N.J. : Prentice - Hall.

Olson, Mancur., 1971., The Logic of Collective Action., Cambridge - Harvard University Press.

Perda Kab. Bantul No 3/2005., tentang Perizinan Usaha Jasa Pariwisata Kabupaten Bantul

Perda Kab. Bantul No 5 tahun 2003., tentang Pembentukan Dinas Kebudayaan dan Pariwisata

Pratikno (ed).,2007, Kerjasama Antar Daerah: Kompleksitas dan Tawaran Format Kelembagaan ; Yogyakarta - Polokda JIP UGM

Putranti., Heni Ari., 2012., Dampak Kebijakan Pengelolaan Kawasan Pantai Lagoi oleh Investor Asing terhadap masyarakat Setempat dan Pemerintah Daerah Riau; Thesis, Jurusan Perencanaan Wilayah Dan Kota, Univeristas Diponegoro

Rosen, E.D. 1993. Improving Public Sector Productivity: Concept and Practice. London: Sage Publications, International Educational and Professional Publisher.

Ruswanto, Wawan., 2009., Kelembagaan Transportasi Kota Medan;Jurnal On line pada Portal Garuda Kemendiknas; Disertasi Universitas Indonesia (http://garuda.kemdiknas.go.id/jurnal/detil/id/90:12487/q/transportasi\%20kota\%20 medan/offset/0/limit/15)

Wibowo, Mardi., 2012., Sistem Jaringan Kelembagaan dalam Pengelolaan Lingkungan Pantai., Jurnal Teknologi Lingkungan, Vol. 3, No. 3, September 2012: 218-225 JURNAL DAN MEDIA MASSA: http://krjogja.com/read/164917/pembahasanraperda-penyelenggaraan-pariwisata.kr 